\author{
В. В. Дармостук ${ }^{1}$, аспірант \\ Ю. А. Ходосовцева ${ }^{2}$, к.б.н., доцент \\ О. С. Ходосовцев ${ }^{1}$, д.б.н., професор \\ ${ }^{1}$ Херсонський державний університет \\ вул. Університетська, 27, м. Херсон, 73000, Україна, e-mail: valeriy_d@i.ua \\ ${ }^{2}$ Херсонський державний аграрний університет \\ вул. Рози Люксембург, 23, Херсон 73006, Україна, e-mail: geleverya@i.ua

\section{ПЕРШІ ВІДОМОСТІ ПРО ЛИШАЙНИКИ ТА ЛІХЕНОФІЛЬНІ ГРИБИ НАЦІОНАЛЬНИХ ПРИРОДНИХ ПАРКІВ «НИЖНЬОСУЛЬСЬКИЙ» ТА «ПИРЯТИНСЬКИЙ»}

\begin{abstract}
На території національного природного парку «Нижньосульський» виявлено 54 види лишайників та 6 видів ліхенофільних грибів. Ліхенобіота національного природного парку «Пирятинський» репрезентує 55 видів лишайників та 4 види ліхенофільних грибів. Домінуючою екологічною групою є епіфіти, що зростають на корі листяних порід дерев. Лишайники Arthonia mediella, Caloplaca obscurella та Dimerella pineti вперше наведено для Лівобережного лісостепу. Сім видів лишайників (Arthrosporum populorum, Buellia griseovirens, Phlyctis argena, Piccolia ochrophora, Rinodina pityrea, Trapeliosis granulosa, Xanthoria candelaria) та три види ліхенофільних грибів (Athelia arachnoidea, Erythricium aurantiacum, Xanthoriicola physciae) виявились новими для Полтавської області.
\end{abstract}

Ключові слова: Лівобережний Лісостеп; Arthonia; Caloplaca; Dimerella.

Молоді національні природні парки (НПП) Полтавщини «Пирятинський» (рис. 1а) та «Нижньосульский» (рис. 1б), які створені один за одним у грудні 2009 р. (на площі 12028,42 га) та лютому 2010 р. (на площі 18653,11 га) відповідно [8], потребують всебічної інвентаризації біорізноманіття. Їх території мають кластерний характер і складаються із окремих урочищ, що репрезентують лісостепові біотопи заплави річок Сула, Удай, Перевод, Руда.

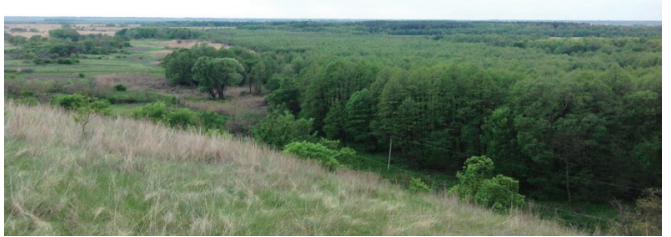

$a$

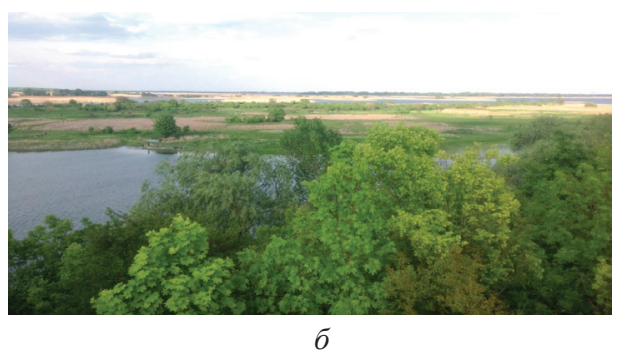

Рис. 1. Біотопи національного природного парку «Пирятинський» (а) та «Нижньосульский» (б) 
У заплавах добре збереглася лісова рослинність (наприклад, 19,2 \% в національному природному парку «Пирятинський»), що представлена фітоценозами за участю Acer platanoides, A. campestre, Quercus robur, Populus nigra та Salix alba. 3 лісовими біотопами консортивно пов'язані лишайники. Однак, дані щодо репрезентативності їх на природно-заповідних територіях Полтавщини наводяться на кінець минулого століття [1], а інформація щодо ліхенологічних досліджень на цій території майже відсутня крім трьох видів лишайників, наведених для сучасних меж національного природного парку «Пирятинський». Отже, метою було сучасне дослідження лишайників та ліхенофільних грибів на території НПП «Пирятинський» та «Нижньосульский».

\section{Матеріали та методи досліджень}

Лишайники та ліхенофільні гриби збиралися 1-5 травня 2016 року в таких локалітетах національних природних парків (НПП) «Нижньосульский» та «Пирятинський» (рис. 2):
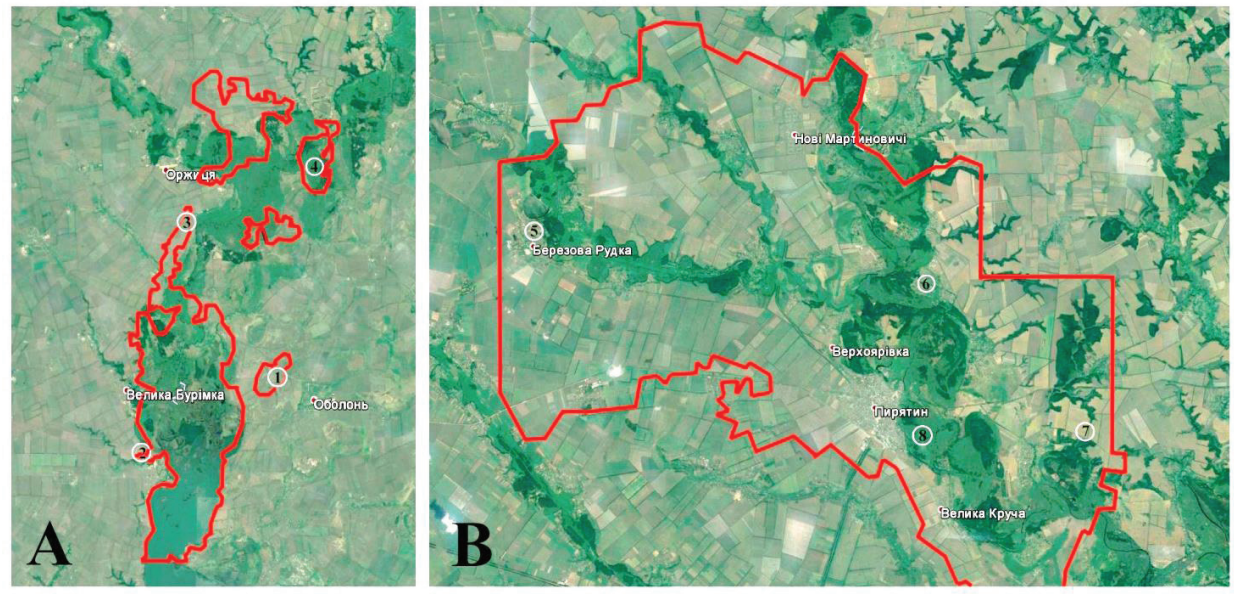

Рис. 2. Місия зборів лишайників та ліхенофільних грибів: А - НПП «Нижньосульский», В - НПП «Пирятинський»

1. Полтавська обл., Семенівський р-н, біля с. Оболонь, НПП «Нижньосульский», 49॰33'2" N, 3251'35.8" E, alt. 72 m, 03.05.2016, Ходосовцев О. Є., Дармостук В. В., Ходосовцева Ю. А.

2. Черкаська обл., Чорнобаївський р-н, біля с. Лящівка, НПП «Нижньосульский», 49³2'39.7" N, 32³9'26.6" E, alt. 54 m, 03.05.2016, Ходосовцев О. Є., Дармостук В. В., Ходосовцева Ю. А.

3. Полтавська обл., Семенівський р-н, біля с. Старий Калкаїв, біля переправи, НПП «Нижньосульский», 4943'26.3" N, 3243'45.7"Е, alt. 90 m, 03.05.2016, Ходосовцев О. Є., Дармостук В. В., Ходосовцева Ю. А. 
4. Полтавська обл., Семенівський р-н, біля с. Худоліївка, НПП «Нижньосульский», 49²5'55.1" N, 3254'34" E, alt. 108 m, 04.05.2016, Ходосовцев О. С., Дармостук В. В., Ходосовцева Ю. А.

5. Полтавська обл, Пирятинський р-н, біля с. Березова Рудка, 50²18'18.23" $\mathrm{N}, 32^{\circ} 13^{\prime} 59.01^{\prime \prime} \mathrm{E}$, alt. $119 \mathrm{~m} \mathrm{[1].}$

6. Полтавська обл., Пирятинський р-н, біля с. Дейманівка, НПП «Пирятин-

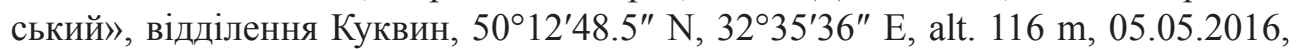
Ходосовцев О. Є., Дармостук В. В., Ходосовцева Ю. А.

7. Полтавська обл., Пирятинський р-н, біля с. Дейманівка, НПП «Пирятинський», відділення Шкуроти, 50²12'32.1" N, 3240'33.1" E, alt. 130 m, 05.05.2016, Ходосовцев О. Є., Дармостук В. В., Ходосовцева Ю. А.

8. Полтавська обл., Пирятинський р-н, біля м. Пирятин, Острів Масальський, НПП «Пирятинський», 4943'49" N, 3247'52.6" E, alt. 87 m, 05.05.2016, Ходосовцев О. Є., Дармостук В. В., Ходосовцева Ю. А.

Ідентифікація видів проводилась в лабораторії біорізноманіття та екологічного моніторингу Херсонського державного університету. Зібраний матеріал визначали за стандартною методикою [16]. Визначені зразки зберігаються в ліхенологічному гербарії Херсонського державного університету (KHER). Назви лишайників і ліхенофільних грибів та прізвища авторів при таксонах подано за Index Fungorum. У даній роботі після кожного виду наведені еколого-субстратні особливості та локалітети. Позначкою «*» відмічено ліхенофільні гриби.

\section{Результати досліджень та їх обговорення}

\section{Анотований список лишайників}

Amandinea punctata (Hoffm.) Coppins \& Scheid. - НПП «Нижньосульський» $(2,4)$ на корі Robinia pseudoacacia, Quercus robur; НПП «Пирятинський» $(6,8)$ на корі $Q$. robur.

A. dispersa Dufour - НПП «Пирятинський» (5) на корі Acer pseudoplatanus [1].

A. mediella Nyl. - НПП «Нижньосульський» (4) на корі Q. robur.

A. punctiformis Ach. - НПП «Пирятинський» (6) на корі Betula pendula.

A. sp. - НПП «Пирятинський» (6) на корі B. verrucosa.

Arthrosporum populorum A. Massal. - НПП «Нижньосульський» (3) на корі Populus alba.

Athallia pyracea (Ach.) Arup, Frödén \& Søchting - НПП «Нижньосульський» $(2,3)$ на корі P. alba, R. pseudoacacia; НПП «Пирятинський» (6) на корі P. alba.

*Athelia arachnoidea (Berk.) Julich - НПП «Нижньосульський» $(2,4)$ на Physcia adscendens, на корі $R$. pseudoacacia; НПП «Пирятинський» (8) на $P$. adscendens, на корі $Q$. robur.

Bacidia bagliettoana (A. Massal. \& De Not.) Jatta - НПП «Пирятинський» (7) на грунті. 
Bacidia rubella (Hoffm.) A. Massal. - НПП «Нижньосульський» (4) на корі Q. robur.

Buellia griseovirens (Turner \& Borrer ex Sm.) Almb. - НПП «Пирятинський» (6) на корі B. verrucosa.

Caloplaca obscurella (J. Lahm) Th. Fr. - НПП «Нижньосульський» (4) на корі Q. robur.

Candelariella efflorescens R. C. Harris \& W. R. Buck - НПП «Нижньосульський» $(2,4)$ на корі $R$. pseudoacacia; НПП «Пирятинський» $(6,8)$ на корі $Q$ robur.

C. faginea Nimis, Poelt \& Puntillo - НПП «Нижньосульський» (4) на корі Q. robur.

C. xanthostigma (Ach.) Lettau - НПП «Нижньосульський» (2) на корі R. pseudoacacia.

Carbonicola myrmecina (Ach.) Bendiksby \& Timdal - НПП «Нижньосульський» (4) на корі Pinus sylvestris; НПП «Пирятинський» $(6,8)$ на корі $Q$. robur.

Chaenotheca trichialis (Ach.) Hellb. - НПП «Нижньосульський» (4) на корі Q. robur; НПП «Пирятинський» (8) на корі Q. robur.

Cladonia coniocraea (Flörke) Spreng - НПП «Нижньосульський» (4) на корі Q. robur; НПП «Пирятинський» (6) на корі Q. robur.

C. fimbriata (L.) Fr. - НПП «Нижньосульський» (4) на піску; НПП «Пирятинський» (6) на корі B. verrucosa.

C. subulata (L.) Weber ex F. H. Wigg - НПП «Нижньосульський» (4) на піску; НПП «Пирятинський» (6) на корі $B$. verrucosa.

Dimerella pineti (Ach.) Vězda - НПП «Нижньосульський» (4) на корi Q. robur.

Diploschistes muscorum (Scop.) R. Sant - НПП «Пирятинський» (7) на грунті.

Enchylium limosum (Ach.) Otálora, P. M. Jørg. \& Wedin - НПП «Пирятинський» (5) на грунті [1].

E. tenax (Sw.) Gray - НПП «Нижньосульський» (1) на грунті.

*Erythricium aurantiacum (Lasch) D. Hawksw. \& A. Henrici - НПП «Нижньосульський» (4) на $P$. adscendens, на корі $Q$. robur; НПП «Пирятинський» на $P$. adscendens, на корі $Q$. robur.

Evernia prunastri (L.) Ach. - НПП «Нижньосульський» $(3,4)$ на корі $P$. alba, Q. robur; НПП «Пирятинський» $(6,8)$ на корі $Q$. robur.

*Homostegia piggotii (Berk. \& Broome) P. Karst. - НПП «Нижньосульський» (4) на слані Parmelia sulcata, на корі Q. robur.

Hypogymnia physodes (L.) Nyl. - НПП «Нижньосульський» (4) на корі Q. robur, P. sylvestris; НПП «Пирятинський» $(6,8)$ на корі $Q$. robur.

H. tubulosa (Schaer.) Hav. - НПП «Нижньосульський» (4) на корі P. sylvestris; НПП «Пирятинський» (6) на корі Q. robur.

Graphis scripta (L.) Ach. - НПП «Нижньосульський» (4) на корі Q. robur.

Lecania cyrtella (Ach.) Th. Fr. - НПП «Нижньосульський» (3) на корі P. alba. 
L. fuscella (Schaer.) A. Massal. - НПП «Нижньосульський» (3) на корі P. alba.

L. naegelii (Hepp) Diederich \& Van den Boom - НПП «Нижньосульський» (3) на корі $P$. alba; НПП «Пирятинський» (6) на корі $Q$. robur.

Lecanora carpinea (L.) Vain. - НПП «Нижньосульський» $(2,4)$ на корі Robinia, Q. robur; НПП «Пирятинський» (6) на корі Q. robur.

L. symmicta (Ach.) Ach. - НПП «Пирятинський» (6) на корі B. verrucosa.

L. varia (Hoffm.) Ach - НПП «Нижньосульський» (4) на корі P. sylvestris.

Lecidella elaeochroma (Ach.) M. Choisy - НПП «Нижньосульський» (4) на корі Quercus; НПП «Пирятинський» (6) на корі Q. robur.

Lepraria lobificans Nyl. - НПП «Пирятинський» (8) на корі Q. robur.

L. incana (L.) Ach. - НПП «Нижньосульський» (4) на корі Q. robur; НПП «Пирятинський» $(6,8)$ на корі $Q$. robur.

Leptorhaphis atomaria (Ach.) Szatala - НПП «Нижньосульський» (3) на корі P. alba.

*Lichenoconium erodens M. S. Christ. \& D. Hawksw. - НПП «Пирятинський» (6) на Parmelia sulcata, на корі Q. robur.

Massjukiella polycarpa (Hoffm.) S. Y. Kondr., Fedorenko, S. Stenroos, Kärnefelt, Elix, J. S. Hur \& A. Thell - НПП «Нижньосульський» (2) на корі R. pseudoacacia; НПП «Пирятинський» $(6,8)$ на корі $Q$. robur.

Melanelixia subargentifera (Nyl.) O. Blanco, A. Crespo, Divakar, Essl., D. Hawksw. \& Lumbsch - НПП «Нижньосульський» (4) на корі Q. robur.

M. subaurifera (Nyl.) O. Blanco, A. Crespo, Divakar, Essl., D. Hawksw. \& Lumbsch - НПП «Нижньосульський» (4) на корі Q. robur; НПП «Пирятинський» (6) на корі $Q$. robur.

Micarea denigrata (Fr.) Hedl. - НПП «Пирятинський» (6) на корі P. sylvestris.

M. misella (Nyl.) Hedl. - НПП «Нижньосульський» (4) на корі P. sylvestris.

Mycobilimbia sabuletorum (Schreb.) Hafellner - НПП «Пирятинський» (7) на грунті.

Myriolecis hagenii (Ach.) Śliwa, Zhao Xin \& Lumbsch - НПП «Нижньосульський» (3) на корі P. alba; НПП «Пирятинський» (6) на корі P. alba.

M. saligna (H. Magn.) Śliwa, Zhao Xin \& Lumbsch - НПП «Нижньосульський» (4) на корі $Q$. robur; НПП «Пирятинський» (6) на корі $Q$. robur.

Pachyphiale carneola (Ach.) Arnold - НПП «Нижньосульський» (4) на корі Q. robur.

Parmelia sulcata Taylor - НПП «Нижньосульський» (4) на корі Q. robur; НПП «Пирятинський» $(6,8)$ на корі $Q$. robur.

Parmelina quercina (Willd.) Hale - НПП «Пирятинський» (6) на корі Q. robur. P. tiliacea (Hoffm.) Hale - НПП «Пирятинський» $(6,8)$ на корі $Q$. robur.

Parmeliopsis ambigua (Wulfen) Nyl. - НПП «Пирятинський» (6) на корі B. verrucosa.

Peltigera didactyla (With.) J. R. Laundon - НПП «Пирятинський» (7) на грунті. 
Phaeophyscia orbicularis (Neck.) Moberg - НПП «Нижньосульський» (2, 3, 4) на корі P. alba, R. pseudoacacia; НПП «Пирятинський» $(6,8)$ на корі $Q$. robur.

P. nigricans (Flörke) Moberg - НПП «Нижньосульський» (3) на корі P. alba; НПП «Пирятинський» (8) на корі $Q$. robur.

Phlyctis argena (Ach.) Flot. - НПП «Нижньосульський» (4) на корі Q. robur; НПП «Пирятинський» (6) на корі Q. robur.

Physcia adscendens (Fr.) H. Olivier - НПП «Нижньосульський» $(2,3,4)$ на корі P. alba, Q. robur, R. pseudoacacia; НПП «Пирятинський» (8) на корі Q. robur.

P. dubia (Hoffm.) Lettau - НПП «Нижньосульський» (4) на корі Q. robur; НПП «Пирятинський» (6) на корі $Q$. robur.

P. stellaris (L.) Nyl. - НПП «Нижньосульський» (4) на корі Q. robur; НПП «Пирятинський» (6) на корі $Q$. robur.

P. tenella (Scop.) DC. - НПП «Пирятинський» (6) на корі Q. robur.

Physconia enteroxantha (Nyl.) Poelt - НПП «Нижньосульський» (4) на корі Q. robur; НПП «Пирятинський» (6) на корі Q. robur.

$P$. grisea (Lam.) Poelt - НПП «Нижньосульський» $(2,4)$ на корі $Q$. robur, R. pseudoacacia; НПП «Пирятинський» $(6,8)$ на корі $Q$. robur.

Piccolia ochrophora (Nyl.) Hafellner - НПП «Нижньосульський» (3) на корі P. alba.

Placynthiella icmalea (Ach.) Coppins \& P. James - НПП «Нижньосульський» (4) на корі P. sylvestris; НПП «Пирятинський» (6) на корі B. verrucosa.

P. oligotropha (J. R. Laundon) Coppins \& P. James - НПП «Нижньосульський» (4) на піску.

Pleurosticta acetabulum (Neck.) Elix \& Lumbsch - НПП «Пирятинський» (6) на корі $Q$. robur.

*Pronectria diplococca J. Kocourková, A. Khodosovtsev, A. Naumovich, O. Vondráková \& J. Motiejnaite - НПП «Нижньосульський» (1) на Enchylium tenax, на грунті [15].

Pseudoevernia furfuracea (L.) Zopf - НПП «Нижньосульський» (4) на корі Q. robur.

Ramalina fraxinea (L.) Ach. - НПП «Пирятинський» (6) на корі Q. robur.

Rinodina pityrea Ropin \& H. Mayrhofer - НПП «Нижньосульський» (3) на корі P. alba.

R. pyrina (Ach.) Arnold - НПП «Нижньосульський» (2) на корі Robinia; НПП «Пирятинський» (6) на корі $Q$. robur.

Scoliciosporum chlorococcum (Graewe in Stenh.) Vezda - НПП «Пирятинський» $(6,8)$ на корі $Q$. robur.

S. sarothamni (Vain.) Vězda - НПП «Нижньосульський» (2) на корі $R$. pseudoacacia.

S. gallurae Vězda \& Poelt - НПП «Нижньосульський» (4) на корі Q. robur.

Steinia geophana (Nyl.) Stein - НПП «Пирятинський» (5) на грунті [1]. 
Thelenella modesta (Nyl.) Nyl. - НПП «Пирятинський» (5) на мертвій деревині [1].

Trapeliopsis flexuosa (Fr.) Coppins \& P. Јames - НПП «Нижньосульський» (4) на корі P. sylvestris; НПП «Пирятинський» (6) на корі B. verrucosa.

T. granulosa (Hoffm.) Lumbsch - НПП «Пирятинський» (6) на корі B. verrucosa.

*Trichoconis hafellneri U.Braun, Khodos., Darmostuk \& Diederich - НПП «Нижньосульський» (3) на Xanthoria parietina, на корі P. alba [13].

Vulpicida pinastri (Scop.) J.-E. Mattsson \& M. J. Lai - НПП «Пирятинський» (6) на корі B. verrucosa.

Xanthoria candelaria (L.) Th. Fr. - НПП «Пирятинський» (8) на корі Q. robur.

$X$. parietina (L.) Th. Fr. - НПП «Нижньосульський» $(2,3,4)$ на корі $P$. alba, R. pseudoacacia; НПП «Пирятинський» (8) на корі Q. robur.

*Xanthoriicola physciae (Kalchbr.) D. Hawksw. - НПП «Нижньосульський» (4) на X. parietina, на корі Q. robur; НПП «Пирятинський» на Xanthoria parietina, на корі $Q$. robur.

\section{Обговорення}

У ході проведеного дослідження встановлено, що ліхенобіота НПП «Нижньосульський» складає 54 види лишайників та 6 видів ліхенофільних грибів, а на території НПП «Пирятинський» виявлено 55 видів лишайників та 4 види ліхенофільних грибів.

Ліхенобіота НПП «Нижньосульський» майже повністю представлена епіфітами (50 видів, або 92 \%). Дуб є однією з найцінніших порід дерев, що зберігає різноманіття епіфітних лишайників. Найбільш цінні дубові насадження розташовані в околицях села Худоліївка (Семенівський району, Полтавська область). Подібні дубові гайки репрезентують специфічну ліхенобіоту. Тут знайдені Arthonia mediella, Bacidia rubella, Caloplaca obscurella, Candelariella faginea, Chaenotheca trichialis, Dimerella pineti, Graphis scripta, Pachyphiale carneola. Серед виявлених видів Arthonia mediella, що був відомий з Закарпатської [3] та Кіровоградської [5] областей; Caloplaca obscurella, що відмічався з Кримського півострова [4], Кіровоградської [5] та Херсонської [11] областей, та Dimerella pineti, що колекціонувалася з Волинської [7], Закарпатської [3] та Львівської [6] областей, виявилися новими для Лівобережного Лісостепу України.

На території парку «Нижньосульський», по берегах річки, представлені невеликі тополеві гайки. На корі Populus nigra виявлено 15 видів лишайників, серед яких домінантами виступають Athallia pyracea, Lecania cyrtella, Lecanora carpinea, Lecidella elaeochroma, Phaeophyscia nigricans, Xanthoria parietina. Рідше зустрічаються Arthrosporum populorum, Lecania fuscella, L. naegelii, Myriolecis hagenii, Piccolia ochrophora, Rinodina pityrea. Серед досліджених видів, три 
виявились новими для Полтавської області - Arthrosporum populorum, Piccolia ochrophora та Rinodina pityrea.

На корі Robinia pseudoacacia виявлено 14 видів лишайників, серед яких домінантами є Amandinea punctata, Candelariella xanthostigma, Lecanora carpinea, Massjukiella polycarpa, Physcia adscendens, Scoliciosporum sarothamni. Меншою кількістю представлено різноманіття лишайників на корі Pinus sylvestris. Тут зростає 8 видів, серед яких звичайними є Carbonicola myrmecina, Hypogymnia physodes, Lecanora varia, Micarea misella, Placynthiella icmalea, Trapeliopsis flexиоsa, тощо.

На території національного парку «Нижньосульський» виявлено 6 видів ліхенофільних грибів. Серед них виявлено нещодавно відкритий вид Trichoconis hafellneri на Athallia pyracea та Xanthoria parietina, що також відомий з Півдня України [13]. Ліхенофільний гриб Pronectria diplococca, що мешкає в слані Enchylium tenax знайдений вдруге в світі після його опису $[14,15]$. Homostegia piggotii, що зростає на слані Parmelia sulcata, $є$ рідкісним в Україні і був відомий з АР Крим [9], Івано-Франківської [10] та Херсонської [2, 12] областей. Всі вищезазначені види $є$ новими для Лісостепової зони України, а ліхенофільні гриби Athelia arachnoidea, Erythricium aurantiacum та Xanthoriicola physciae виявилися новими для Полтавської області.

Ліхенобіота НПП «Пирятинський» також в основному представлена епіфітами (46 видів, або 82 \%). Значні лісові масиви з домінуванням Quercus robur та Betula verrucosa представлені у заповідному урочищі місцевого значення «Куквин», що входить до складу національного природного парку. Тут виявлено 38 видів лишайників. На корі Quercus robur відмічено Candelariella efflorescens, Evernia prunastri, Lecanora carpinea, Melanelixia. subaurifera, Parmelina quercina. На стовбурах Betula verrucosa зростають помірно ацидофільні види Arthonia punctiformis, Buellia griseovirens, Lecanora symmicta, Parmeliopsis ambigua, Trapeliosis granulosa, Vulpicida pinastri. Серед них, такі види як Buellia griseovirens, Trapeliosis granulosa та Vulpicida pinastri вперше наводяться для Полтавської області.

На території ботанічної пам'ятки природи місцевого значення «Лісопарк Острів Масальський», що також входить до складу національного природного парку, виявлено 24 види лишайників, що приурочені до старих Quercus robur. Серед них рідкісними виявилися Lepraria lobificans, Parmelina quercina, Phlyctis argena та Xanthoria candelaria, дві останні знахідки є новими для Полтавської області.

Епігейні лишайники $є$ дуже рідкісними і переважно пов'язані із слабко зарослими схилами ярів та балок. Саме в таких біотопах зустрічаються Bacidia bagliettoana, Diploschistes muscorum, Mycobilimbia subulatorum та Peltigera didactyla. Лишайники Bacidia bagliettoana та Peltigera didactyla у рівнинних ландшафтах України є вразливими і потребують охорони на місцевому рівні. 


\section{Висновки}

1. Ліхенобіота НПП «Нижньосульський» складає 54 види лишайників та 6 видів ліхенофільних грибів, а на території НПП «Пирятинський» виявлено 55 видів лишайників та 4 види ліхенофільних грибів.

2. Лишайники Arthonia mediella, Caloplaca obscurella та Dimerella pineti вперше наведено для Лівобережного лісостепу. Сім видів лишайників (Arthrosporum populorum, Buellia griseovirens, Phlyctis argena, Piccolia ochrophora, Rinodina pityrea, Trapeliosis granulosa, Xanthoria candelaria) та три види ліхенофільних гриба (Athelia arachnoidea, Erythricium aurantiacum, Xanthoriicola physciae) виявилися новими для Полтавської області.

3. Домінуючою екологічною групою в обох національних природних парках є епіфіти, яких в НПП «Нижньосульський» знайдено 50 видів $(92 \%)$ та 46 видів в НПП «Пирятинський» (82\%), що приурочені до зростання на корі листяних порід дерев Betula, Populus, Robinia та Quercus. Епігейні лишайники Bacidia bagliettoana та Peltigera didactyla в рівнинних ландшафтах України $є$ вразливими і потребують охорони на місцевому рівні.

\section{Подяки}

Автори вдячні професору І. Ю. Костікову, доценту О. М. Сенчилі та їх родинам за гостинність під час перебування в НПП «Нижньосульський» та НПП «Пирятинський», а також постійним учасникам травневих експедицій професору В. П. Поліщуку та доценту О. Ю. Акулову за дружню підтримку.

Стаття надійшла до редакції 20.09.2017

\section{Список використаної літератури}

1. Байрак О. М. Безсудинні рослини Лівобережного Лісостепу України (грунтові водорості, лишайники, мохоподібні) / О. М. Байрак, С. В. Гапон, А. А. Леванець - Полтава: Верстка, 1998. - 160 с.

2. Дармостук В. В. Лишайники та ліхенофільні гриби Русової балки (Великоолександрівський район, Херсонська область) / В. В. Дармостук // Біологічні Студії. - 2016. - 10 (2). - С. 133-140.

3. Окснер А. М. Флора лишайників України / А. М. Окснер. - К.: Вид-во АН УРСР, 1956. - Т. 1 - 410 с.

4. Окснер А. М. Флора лишайників України / А. М. Окснер. - К.: Наук. думка, 1993. - Т.2, Вип.2 - 544 с.

5. Наумович Г. О. Лишайники Чорного лісу (Знам'янський р-н, Кіровоградська обл.) / Г. О. Наумович, О. Є. Ходосовцев // Чорноморськ. бот. ж. - 2008. - 4 (1). - С. 7-13.

6. Пірогов М. В. Лишайники Українського Розточчя / М. В. Пірогов // Вісник Львівського університету. Серія біологічна. $-2011 .-55 .-$ С. 52-60.

7. Пірогов М. Примітки до вивчення ліхенобіоти національного природного парку «Північне Поділля» / М. Пірогов, Ю. Шовган // Вісник Львівського університету. Серія біологічна. - 2015. - 69. - С. 93-101.

8. Фіторізноманіття заповідників та національних природних парків України. Ч. 2. Національні природні парки / під. ред. В. А. Онищенка, Т. Л. Андрієнка. - К.: Фітосоціоцентр, 2012. - 580 с.

9. Ходосовцев О. Є. Нові для України та Криму лишайники та ліхенофільні гриби / О. Є. Ходосовцев // Чорноморськ. бот. ж. $-2013 .-9$ (1). - С. 84-88.

10. Ходосовцев О. Є. Перші відомості про лишайники та ліхенофільні гриби природного заповідника «Горгани» / О. Є. Ходосовцев, В. В. Дармостук, А. Б. Громакова, М. Б. Шпільчак // Чорноморськ. бот. ж. 2016. $-12(1)$ - C. 51-63. 
11. Ходосовцев О. Є., Ходосовцева Ю. А. Лишайники та ліхенофільні гриби дендрологічного парку біосферного заповідника «Асканія-Нова» ім. Ф. Е. Фальц-Фейна / О. Є. Ходосовцев, Ю. А. Ходосовцева // Чорноморськ. бот. ж. - 2014. - 10 (4). - С. 515-526.

12. Ходосовцев О. Є., Ходосовцева Ю. А. Лишайники та ліхенофільні гриби національного природного парку «Олешківські піски» (Херсонська область, Україна) / О. Є. Ходосовцев, Ю. А. Ходосовцева // Чорноморськ. бот. ж. - 2015. - 11 (1). - C. 51-56.

13. Braun U. Trichoconis hafellneri sp. nov. on Xanthoria parietina and Athallia pyracea, a generic discussion of Trichoconis and keys to the species of this genus / U. Braun, A. Ye. Khodosovtsev, V. V. Darmostuk, P. Diederich // Herzogia. - 2016. - 29 (2). - P. 307-314.

14. Khodosovtsev A. Three new Pronectria species in terricolous and saxicolous microlichen communities (Bionectriaceae, Ascomycota) / A. Khodosovtsev, J. Vondrák, A. Naumovich, J. Kocourková, O. Vondrákova, J. Motiejūnaitė // Nova Hedwigia. - 2012. - 95. - P. 211-220.

15. Khodosovtsev A. Ye. Zwackhiomyces polischukii sp. nov., and other noteworthy lichenicolous fungi from Ukraine / A. Ye. Khodosovtsev, V. V. Darmostuk // Polish Botanical Journal. - 2017. - 62 (1). - P. $27-35$.

16. Smith C. W The Lichens of Great Britain and Ireland / C. W Smith et al. - Nat. Hist. Mus. Publ., 2009. $1046 \mathrm{p}$.

\section{В. В. Дармостук ${ }^{1}$ Ю. А. Ходосовцева ${ }^{2}$ А. Е. Ходосовцев ${ }^{1}$}

'Херсонский государственный университет

ул. Университетская, 27, Херсон, 73000, Украина, e-mail: valeriy d@i.ua

${ }^{2}$ Херсонский государственный аграрный університет

ул. Розы Люксембург, 23, Херсон 73006, Украина, e-mail: geleverya@i.ua

\section{ПЕРВЫЕ СВЕДЕНЬЯ О ЛИШАЙНИКАХ И ЛИХЕНОФИЛЬНЫХ ГРИБАХ НАЦИОНАЛЬНЫХ ПРИРОДНЫХ ПАРКОВ «НИЖНЕСУЛЬСКИЙ» И «ПЫРЯТИНСКИЙ»}

\section{Резюме}

Проблема. На сегодняшний день заповедные территории Полтавской области остаются малоизученными. Цель. Исследование лишайников и лихенофильных грибов на территории двух национальных природных парков. Методи. Сборы проводили маршрутно-экспедиционным методом, лишайники и лихенофильные грибы определяли согластно стандартной методике. Результаты. На территории национального природного парка «Нижнесульский» найдено 54 вида лишайников и 6 видов лихенофильных грибов. Лихенобиота национального природного парка «Пырятинский» представлена 55 видами лишайников и 4 видами лихенофильных грибов. Наибольшим числом видов представлены эпифиты, которые растут на коре лиственых пород деревьев, в основном Betula, Populus, Robinia и Quercus (50 видов в НПП «Нижнесульский» и 46 видов на територии НПП «Пырятинский»). Лишайники Arthonia mediella, Caloplaca obscurella и Dimerella pineti впервые указаны для Левобережной Лесостепной зоны Украины. Семь видов лишайников (Arthrosporum populorum, Buellia griseovirens, Phlyctis argena, Piccolia ochrophora, Rinodina pityrea, Trapeliosis granulosa, Xanthoria candelaria) и три вида лихенофильных грибов (Athelia arachnoidea, Erythricium aurantiacum, Xanthoriicola physciae) являются новыми для Полтавской области. Эпигейные виды Bacidia bagliettoana и Peltigera didactyla редко встречаются на территории равнинной Украины и нуждаются в защите на местном уровне. Лихенофильные грибы Pronectria diplococca на Enchylium tenax и Homostegia piggotii на Parmelia sulcata впервые найдены на 
территории Левобережной Лесостепной зоны Украины. Выводы. Таким образом, видовое разнообразие лишайников обоих НПП является типичным для лесостепной зоны и нуждается в охране.

Ключевые слова: Левобережная Лесостепная зона; Arthonia; Caloplaca; Dimerella.

\author{
V. V. Darmostuk ${ }^{1}$, Yu. A. Khodosovtseva ${ }^{2}$, A. Ye. Khodosovtsev ${ }^{1}$ \\ ${ }^{1}$ Kherson State University \\ 27, Universitetsyka str., Kherson, 73000, Ukraine, valeriy_d@i.ua \\ ${ }^{2}$ Kherson State Agrarian University \\ 23, Stritenska str., Kherson, 73006, Ukraine, geleverya@i.ua
}

\title{
LICHENS AND LICHENICOLOUS FUNGI OF NATIONAL NATURE PARKS «NYZHNOSULSKY» AND «PYRYATYNSKY»
}

\begin{abstract}
Introduction. Currently, the protected areas of the Poltava region remain poorly understood. Purpose. This is a comprehensive study of the lichens and lichenicolous fungi on the territory of two National Nature Parks (NNPs). Methods. Collecting was carried out by the route-expedition method. Lichens and lichenicolous fungi were identified in accordance with a standard procedure. Results. NNP «Nyzhnyosulsky» was represented by 54 species of the lichens and 6 species of the lichenicolous fungi. 55 species of the lichens and 4 species of the lichenicolous fungi were found on the territory of the NNP «Pyryatynsky». Corticolous lichens are dominant ecological groups in both National Nature Parks. 50 corticolous species (92\%) were found in NNP «Nyzhnyosulsky» and 46 species $(82 \%)$ were found in NNP «Pyryatynsky». These species are confined to the growth on the bark of the hardwood trees, especially Betula, Populus, Robinia and Quercus. The mature oaks are the most valuable lichen habitat in the parks.

Such species as Arthonia mediella, Bacidia rubella, Caloplaca obscurella, Candelariella faginea, Chaenotheca trichialis, Dimerella pineti, Graphis scripta, Pachyphiale carneola have been found rarely on the oak bark on the plain part of Ukraine. Among them A.mediella, C. obscurella and D. pineti are first time reported for the Left-Bank Forest-Steppe zone of Ukraine. The bark of Populus nigra is a habitat for a few rare species, such as Arthrosporum populorum, Lecania fuscella, Piccolia ochrophora and Rinodina pityrea. Rare species in Ukrainian plain $A$. cinereopruinosa, Buellia griseovirens, Lecanora symmicta, Parmeliopsis ambigua, Trapeliosis granulosa, Vulpicida pinastri were found on the bark of Betula verrucosa in NNP «Pyryatynsky». A. cinereopruinosa is a new one for Left-Bank ForestSteppe zone. Seven species of lichens (A. populorum, B. griseovirens, P. argena, $P$. ochrophora, $R$. pityrea, T. granulosa, X. candelaria) and three species of lichenicolous fungi (Athelia arachnoidea, Erythricium aurantiacum, Xanthoriicola physciae) are first time reported for the Poltava region.

Terricolous lichens such as Bacidia bagliettoana, Diploschistes muscorum, Mycobilimbia subulatorum and Peltigera didactyla are usually associated with weakly overgrown slopes of the ravines and beams. Terricolous lichens $B$. bagliettoana and $P$. didactyla are vulnerable in lowland landscapes of Ukraine and need to
\end{abstract}


be protected at the local level. Lichenicolous fungi Pronectria diplococca on Enchylium tenax and Homostegia piggotii on Parmelia sulcata are new for Left-Bank Forest-Steppe zone. Conclusion. Thus, the species diversity of lichens of both NPPs is typical of the forest-steppe zone and needs to be protected.

Key words: Left-Bank Forest-Steppe zone; Arthonia; Caloplaca; Dimerella.

\section{References}

1. Bairak O. M, Gapon S. V., Levanets A. A. (1998) Non-vascular plants of the Left-Bank Forest-Steppe of Ukraine (soil alge, lichens, mosses) [Bezsudynni roslyny Livoberezhnoho Lisostepu Ukrainy (hruntovi vodorosti, lyshaynyky, mokhopodibni)], Verstka, Poltava, $160 \mathrm{p}$.

2. Darmostuk V. V. (2016) "Lichens and lichenicolous fungi of the Rusova beam (Velykooleksandrivka district, Kherson region)" ["Lyshaynyky ta likhenofilni hryby Rusovoi balky (Velykooleksandrivskyi r-n, Khersonska oblast)"], Studia Biologica 10(2), pp. 133-140.

3. Oksner A. M. (1956) Lichen flora of Ukraine [Flora lyshaynykiv Ukrainy], Kiev: V-vo AN URSR, 1, 410 p.

4. Oksner A. M. (1993) Lichen flora of Ukraine [Flora lyshaynykiv Ukrainy], Kiev: Nauk. Dumka, 2(2), 544 p.

5. Naumovich H. O., Khodosovtsev A. Ye. (2008) "The lichens of Black Forest (Znamenivskiy district, Kirovograds'ka oblast)" ["Lyshaynyky Chornoho lisu (Znam'yanskyi r-n, Kirovohradska oblast)"], Chornomors'k. bot. z., 4(1), pp. 7-13.

6. Pirogov M. (2011) "Lichens of Ukrainian Roztochya" ["Lyshaynyky Ukrayinskoho Roztochchya"], Visnyk of the Lviv University. Series Biology, 69, pp. 93-101.

7. Pirogov M, Shovhan Yu. (2015) "Notes on the lichen biota of national nature park «Pivnichne Podilla»" ["Prymitky do vyvchennya likhenobioty natsionalnoho pryrodnoho parku «Pivnichne Podillya»"], Visnyk of the Lviv University. Series Biology, 55, pp. 52-60.

8. Onyshchenko V. A., Andrienko T. L. (ed.) (2012) Phytodiversity of nature reserves and national nature parks of Ukraine. P.2. National nature parks. [Fitoriznomanittya zapovidnykiv i natsionalnykh pryrodnykh parkiv Ukrainy. Ch.2. Natsionalni pryrodni parky], Kiev: Phytosociocentre, 580 p.

9. Khodosovtsev A. Ye. (2013) "Lichen-forming and lichenicolous fungi from Aju-Dag Mt new to Ukraine and Crimea" ["Novi dlya Ukrainy ta Krymu lyshaynyky ta likhenofilni hryby”], Chornomors`k. bot. z., 9(1), pp. 84-88.

10. Khodosovtsev A. Ye., Darmostuk V. V. (2017) "Zwackhiomyces polischukii sp. nov., and other noteworthy lichenicolous fungi from Ukraine”, Polish Botanical Journal, 62(1), pp. 27-35.

11. Khodosovtsev A. Ye., Khodosovtseva Yu. A. (2014) "Lichens and lichenicolous fungi of the arboretum F.E. Falz-Fein Biosphere Reserve of "Askania-Nova" ["Lyshaynyky ta likhenofilni hryby dendroparku biosfernoho zapovidnyka «Askaniya-Nova» im. F.E. Falts-Feyna”], Chornomors'k. bot. z., 10(4), pp. 515-526.

12. Khodosovtsev A. Ye., Khodosovtseva Yu. A. (2015) "The lichens and lichenicolous fungi of National Nature Park "Oleshkivs`ki pisky" (Kherson region, Ukraine)" ["Lyshaynyky ta likhenofilni hryby Natsionalnoho pryrodnoho parku «Oleshkivski pisky» (Khersonska oblast, Ukraina)”], Chornomors'k. bot. z., 11(1), pp. $51-56$.

13. Khodosovtsev A. Ye., Darmostuk V. V., Gromakova A. B., Shpilchak M. B. (2016) "A first contribution to lichens and lichenicolous fungi of the Nature Reserve "Gorgany" (Ukraine)" "Pershi vidomosti pro lyshaynyky ta likhenofilni hryby pryrodnoho zapovidnyka «Horhany»"], Chornomors'k. bot. z., 12(1), pp. 51-63.

14. Khodosovtsev A., Vondrák J., Naumovich G., Kocourková J., Vondrákova O., Motiejūnaitė J. (2012) “Three new Pronectria species in terricolous and saxicolous microlichen communities (Bionectriaceae, Ascomycota)", Nova Hedwigia, 95, pp. 211-220.

15. Braun U., Khodosovtsev A. Ye., Darmostuk V. V., Diederich P. (2016) "Trichoconis hafellneri sp. nov. on Xanthoria parietina and Athallia pyracea, a generic discussion of Trichoconis and keys to the species of this genus", Herzogia 29(2), pp. 307-314.

16. Smith C. W., Aptroot B. J., Coppins B. J., Flecher A., Gilbert O. L., James P. W., Wolseley P. A. (2009) The Lichens of Great Britain and Ireland. Nat. Hist. Mus. Publ.: 1046 p. 